\section{Glyphosate Efficacy as Influenced by Cultivation Practices on a Creeping Bentgrass Fairway Turf}

\author{
Kevin M. Miele ${ }^{1}$, Jason J. Henderson ${ }^{2}$, and John C. Inguagiato ${ }^{3,4}$ \\ Department of Plant Science, University of Connecticut, Storrs, CT 06269
}

Additional index words. verticutting, aerification, renovation, Agrostis stolinifera, glyphosate, creeping bentgrass, Poа апnиa, annual bluegrass

\begin{abstract}
Glyphosate is routinely used to eradicate existing turf in golf course fairway renovations. However, current label recommendations suggest delaying cultivation of glyphosate treated areas for 7 days. A 2-year field study was conducted to assess how various seedbed preparation techniques (i.e., verticutting, core-cultivation, or verticutting + core-cultivation) influence glyphosate efficacy on creeping bentgrass fairway turf when completed at various intervals shortly after application [0-7 days before cultivation $(\mathrm{DBC})]$. Percent green cover declined from initial values of $\approx 90 \%$ to $\leq 0.2 \%$ at the end of the study after glyphosate application at all timings, regardless of cultivation during both years. All cultivated plots had $37.9 \%$ to $72.3 \%$, or $5.9 \%$ to $62.1 \%$ less green cover compared with noncultivated plots when glyphosate was applied $\leq 3$ days before cultivation in $\mathbf{2 0 1 4}$ and 2015, respectively. Generally, the number of days until green cover reached $1 \%\left(\mathrm{GC}_{1}\right)$ ranged from 6.6 to 11.1 in 2014 and 5.2 to 6.9 in 2015 . Within glyphosate application timings, no differences in $\mathrm{GC}_{1}$ were observed between cultivated and noncultivated treatments in 2014, except at $\mathbf{0} \mathrm{DBC}$. The $\mathrm{GC}_{1}$ for verticutting was 5.1 days longer than noncultivated plots; however, all other cultivation treatments were equivalent to noncultivated plots when glyphosate was applied 0 DBC. All cultivation treatments reduced $\mathrm{GC}_{1} \mathbf{1 . 7}$ to 2.5 days compared with the no cultivation treatment, regardless of glyphosate application timing in 2015 . Results from this study indicate that cultivation of creeping bentgrass fairway turf within 7 days of glyphosate application is not detrimental to long-term herbicide efficacy, and in some cases may actually enhance the rate of decline of glyphosate treated creeping bentgrass.
\end{abstract}

Fairways are the largest acreage of intensively managed turf on golf courses. On older courses, undesirable turfgrass species, such as annual bluegrass (Poa annua L.) or older cultivars of otherwise desirable species [e.g., creeping bentgrass (Agrostis stolonifera L.)] often make up most existing fairway populations. Extensive breeding efforts over the past few decades have yielded new turfgrass cultivars which offer significant improvements in abiotic and biotic stress tolerance (Bonos and Huff, 2013). Use of improved cultivars in fairways could improve the sustainability of golf facilities by reducing water and pesticide use. However, adoption of improved cultivars in older

\footnotetext{
Received for publication 14 June 2017. Accepted for publication 12 Sept. 2017.

We thank Karl Guillard for assistance with statistical procedures, and Scott Vose and Zoë Esponda for their assistance in maintaining the study areas. This material is based on work that is supported by the National Institute of Food and Agriculture, the U.S. Department of Agriculture, Hatch Multi-State Project NE-1046. Additional support was received from the New England Regional Turfgrass Foundation and the United States Golf Association.

${ }^{1}$ Research Assistant.

${ }^{2}$ Associate Professor.

${ }^{3}$ Assistant Professor

${ }^{4}$ Corresponding author. E-mail: john.inguagiato@ uconn.edu.
}

established fairways has been limited, in part, due to questions regarding optimal renovation procedures and low tolerance for disruption of play during renovation (Skorulski, 2013).

Establishing new cultivars into established turfgrass stands has been shown to be improved by first eliminating the existing turf population with a nonselective herbicide, such as glyphosate (Bauer et al., 2012; Kendrick and Danneberger, 2002). Intraseeding into existing stands of creeping bentgrass using only cultivation techniques, such as scalping or hollowtine cultivation, resulted in a $0 \%$ to $25 \%$ conversion to an improved creeping bentgrass cultivar (Kendrick and Danneberger, 2002). Using the plant growth regulator trinexapacethyl [4-(Cyclopropyl-a-hydroxymethylene)3,5- dioxo-cyclohexanecarboxylic acid ethylester] to suppress existing turf yielded a $0 \%$ to $3 \%$ conversion to an improved creeping bentgrass cultivar in a creeping bentgrass putting green turf (Kendrick and Danneberger, 2002) and had no effect on establishing creeping bentgrass in a mixed cool-season turfgrass fairway (Reicher and Hardebeck, 2002). However, when glyphosate was used, an $88 \%$ conversion to newly seeded creeping bentgrass cultivar was observed (Kendrick and Danneberger, 2002). Similarly, in annual bluegrass fairways, less than $5 \%$ of seeded creeping bentgrass established in the absence of glyphosate; whereas, up to $80 \%$ bentgrass established in plots where glyphosate was applied before seeding (Bauer et al., 2012). These results indicate that the use of a nonselective herbicide before seeding can enhance establishment of new seedlings.

Glyphosate is a systemic, nonselective herbicide which inhibits 5-enolpyruvylshikimate 3-phosphate synthase to prevent production of aromatic amino acids (Amrhein et al., 1980; Steinrucken and Amrhein, 1980). The herbicide is absorbed into plant cells primarily through diffusion, distributed locally via apoplastic and symplastic movement, and translocated throughout the plant via the phloem (Bingham et al., 1980; Hetherington et al., 1998; Segura et al., 1978). Cultivation of creeping grasses following glyphosate application can sever stolons and/or rhizomes which may limit translocation of the herbicide potentially reducing efficacy. Control of torpedograss (Panicum reptans L.) was reduced by $50 \%$ to $63 \%$ and $5 \%$ to $15 \%$ when tillage occurred 1 and $3 \mathrm{~d}$ after application of glyphosate, respectively compared with nontilled glyphosate treated areas (Burt, 1980). Current glyphosate label recommendations suggest avoiding disturbance of soil or underground plant parts through vertical mowing or core cultivation for $7 \mathrm{~d}$ after application to enable translocation of the herbicide (Anonymous, 2010). However, the effect of cultivation timing after glyphosate application on herbicide efficacy is not well known for creeping bentgrass fairway turf. It may be that glyphosate translocates more quickly (i.e., $<7 \mathrm{~d}$ ) through creeping bentgrass and annual bluegrass than taller grass species with deeper more robust rhizomes, such as torpedograss.

Preparing a seedbed through cultivation of the existing turfgrass surface is recognized to be an important component of establishing turfgrass from seed (Turgeon, 2005). However, based on current glyphosate label recommendations, this practice should not occur within $7 \mathrm{~d}$ of herbicide application. At golf courses, where total duration of renovation practices is a concern for turf managers and clientele considering fairway renovation; it may be advantageous to reduce the time between glyphosate application and cultivation to prepare the seedbed to minimize disruption of play at facilities. It is not well understood, however, how cultivation occurring shortly after glyphosate application would affect herbicide efficacy in creeping bentgrass fairway turf. Therefore, the objective of this study is to assess how various seedbed preparation techniques (i.e., verticutting and core-cultivation) influence glyphosate efficacy on creeping bentgrass fairway turf when completed at various intervals shortly after application.

\section{Materials and Methods}

Site description. The 2-year field study was initiated on 20 June 2014 and 30 July 2015 at the University of Connecticut Plant Science Research and Education Facility in Storrs, CT (41 $\left.79^{\prime} 37^{\prime \prime} \mathrm{N} ; 72^{\circ} 22^{\prime} 87^{\prime \prime} \mathrm{W}\right)$. The study was conducted on a 5 and 8 year old 
'L-93' and 'Crenshaw' creeping bentgrass fairway turf grown on a Paxton fine sandy loam (coarse-loamy, mixed, active, mesic Oxyaquic Dystrudepts). Turf was mowed $3 \mathrm{~d} /$ week at a height of $1.3 \mathrm{~cm}$. Nitrogen was applied as water soluble sources totaling 36.6 and $61.0 \mathrm{~kg} \mathrm{~N} / \mathrm{ha}$ from April through the duration of the study in 2014 and 2015 , respectively. Irrigation was applied with overhead irrigation before the initiation of treatments each year to avoid water deficit stress. During the evaluation period irrigation was applied as described below. Dollar spot (caused by Sclerotinia homoeocarpa F.T. Bennett) was treated preventively with fluazinam [3-chloro-N-(3chloro-2,6-dinitro-4-trifluoromethylphenyl)5-trifluoromethyl-2-pyridinamine] at $0.8 \mathrm{~kg}$ a.i./ha on 10 June 2014. White grubs (Popillia japonica Newman, Anomala orientali Waterhouse) were controlled with an application of chlorantraniliprole (3-bromo-N-\{4-chloro2-methyl-6-[(methylamino)carbonyl]phenyl $\}$ 1-(3-chloro-2-pyridinyl)-1H-pyrazole-5carboxarmide) at $0.22 \mathrm{~kg}$ a.i./ha on 6 June 2015 .

Experimental design and treatments. The study was conducted as a $4 \times 5$ factorial arranged in a split-plot design with three blocks. Main plots measured $1.8 \times 5.5 \mathrm{~m}$ and consisted of four cultivation treatments: verticutting, core-cultivation, verticutting + core-cultivation, and no cultivation. Main plots were divided into six subplots, each measuring $0.9 \times 1.8 \mathrm{~m}$, five of which consisted of glyphosate application timings occurring $7,5,3,1$, and $0 \mathrm{DBC}$, with a sixth subplot included as a no glyphosate control.

Cultivation occurred on 27 June 2014 and on 6 Aug. 2015. Verticutting treatments were conducted using a Graden SW04 SwingWing Verticutter (Graden Industries, Thomastown, Victoria, Australia) with $2 \mathrm{~mm}$ wide blades set $52 \mathrm{~mm}$ apart. Plots were verticut in two directions to the depth of the thatch-soil interface $(\approx 2.5 \mathrm{~cm})$. Corecultivation was conducted with a Toro ProCore 648 (The Toro Company, Bloomington, $\mathrm{MN}$ ) outfitted with $1.6 \mathrm{~cm}$ (o.d.) hollow-tines to a depth of $5 \mathrm{~cm}$ set $5 \times 5 \mathrm{~cm}$ apart. Cores were pulverized with a rotary mower and soil was reincorporated into aerification holes and the turf canopy within each core-cultivation or verticutting + core-cultivation subplot using leaf rakes and brooms. For plots that received both types of cultivation, verticutting was performed first and accumulated thatch was removed from the surface before core-cultivation. Following cultivation and for the remainder of the trial, the entire study area was irrigated with $2.5 \mathrm{~mm}$ water three times daily between 0800 and 1900 to simulate conditions following an overseeding event. Glyphosate was applied at $3.42 \mathrm{~kg}$ a.i./ha as Roundup Pro Concentrate $(600 \mathrm{~g}$ a.i./L; Monsanto Company, St. Louis, MO) using a hand held $\mathrm{CO}_{2}$ pressurized spray boom outfitted with a single AI9504E (TeeJet Technologies, Glendale Heights, IL) flat fan banding nozzle calibrated to deliver $406 \mathrm{~L} / \mathrm{ha}$ at $138 \mathrm{kPa}$. The $0 \mathrm{DBC}$ glyphosate treatment was allowed to fully dry on the surface before the initiation of any cultivation treatments.

Data collection and statistical analyses. Percent green cover was assessed using a digital image of each subplot taken within a $0.5 \times 0.6 \mathrm{~m}$ white florescent illuminated box which excluded ambient light and provided for a consistent exposure for all plots. The number of green pixels within each image was divided by the total number of pixels in the image using Sigma Scan v. 3.0 (Systat Software Inc, San Jose, CA) based on the methods developed by Karcher and Richardson (2005). Initial images were acquired 7 DBC, before glyphosate application, and subsequent images were taken $1,6,8,11$, and 28 or $23 \mathrm{~d}$ after cultivation (DAC). Rate of green cover decline was determined from percent green cover data as the number of days required for green cover to decline to $1 \%$ of the plot area $\left(\mathrm{GC}_{1}\right)$ for each experimental unit. Percent green cover data was fit to a three-parameter sigmoidal model:

$$
y=\frac{a}{1+\exp ^{-}\left(x-x_{\mathrm{o}} / b\right)}
$$

Except for experimental units where the upper limits of the model prediction exceeded $100 \%$ green cover. This occurred for treatments where green cover declined immediately after initial observations; in these instances a two-parameter exponential decay model was applied to the data:

$$
y=\exp ^{-}(a x)
$$

Estimated parameters based on the least sums of squares were generated using the Gauss-Newton iterative method of the nonlinear procedure in Statistical Analysis System software v. 9.4 (SAS Institute Inc., Cary, $\mathrm{NC})$. Thereafter, $\mathrm{GC}_{1}$ values were calculated for each experimental unit based on the estimated parameters derived from the model which best fit the observed data.

Percent green cover and $\mathrm{GC}_{1}$ data were analyzed using the general linear model

Table 1. Analysis of variance for glyphosate application timing and cultivation type effects on percent

\begin{tabular}{|c|c|c|c|c|c|c|}
\hline \multirow[b]{3}{*}{ Source of variation } & \multicolumn{6}{|c|}{ Days after cultivation (DAC) } \\
\hline & -7 & 1 & 6 & 8 & 11 & $28 / 23^{z}$ \\
\hline & \multicolumn{6}{|c|}{$P>F$} \\
\hline \multicolumn{7}{|l|}{2014} \\
\hline Glyphosate timing ${ }^{\mathrm{y}}$ & NS & $* * *$ & $* * *$ & $*$ & $* * *$ & NS \\
\hline Cultivation type $\mathrm{e}^{\mathrm{x}}$ & NS & $* *$ & NS & NS & NS & $* *$ \\
\hline Glyphosate $\times$ cultivation & NS & $* * *$ & NS & NS & NS & NS \\
\hline \multicolumn{7}{|l|}{ Pre-planned contrast: } \\
\hline Glyphosate vs. no glyphosate & NS & $*$ & $* * *$ & $* * *$ & $* * *$ & $* * *$ \\
\hline \multicolumn{7}{|l|}{2015} \\
\hline Glyphosate & NS & $* * *$ & $* * *$ & $* *$ & $* *$ & $* *$ \\
\hline Cultivation & NS & $* * *$ & $* *$ & $*$ & NS & NS \\
\hline Glyphosate $\times$ cultivation & NS & $* * *$ & $* *$ & $*$ & $* *$ & $*$ \\
\hline \multicolumn{7}{|l|}{ Pre-planned contrast: } \\
\hline Glyphosate vs. no glyphosate & NS & NS & $* * *$ & $* * *$ & $* * *$ & $* * *$ \\
\hline
\end{tabular}
green cover on creeping bentgrass fairway turf in Storrs, CT during 2014 and 2015.

${ }_{\mathrm{z}}$ Data were collected through 28 DAC in 2014, and 23 DAC in 2015.

${ }^{y}$ Glyphosate was applied at a rate of $5.7 \mathrm{~kg} \cdot \mathrm{ha}^{-1}$ using a hand held $\mathrm{CO}_{2}$ powered spray boom outfitted with a single AI9504E flat fan nozzle calibrated to deliver $406 \mathrm{~L} \cdot \mathrm{ha}^{-1}$ at $137.9 \mathrm{kPa}$. Glyphosate was applied 7, 5, 3,1 , or $0 \mathrm{~d}$ before cultivation.

${ }^{x}$ Treatments included verticutting, core-cultivation, or a combination of both. Verticutting treatments were conducted in two directions with $2 \mathrm{~mm}$ blades at $52 \mathrm{~mm}$ spacing at a depth equal to the soil-thatch interface $(\approx 2.5 \mathrm{~cm})$. Core-cultivation was performed with $1.6 \mathrm{~cm}$ o.d. hollow-tines on a $5 \times 5 \mathrm{~cm}$ spacing to a depth of $5 \mathrm{~cm}$.

NS $=$ nonsignificant; $* * *, * * *$ Significant at the $0.05,0.01$, and 0.001 probability levels, respectively. 
and 2015 (Table 1). Percent green cover declined from initial values of $\approx 90 \%$ to $\leq 0.2 \%$ at the end of the study after glyphosate application at all timings, regardless of cultivation during both years (Fig. 1A and B). Differences in percent green cover among glyphosate application timings ranging from 7 to $0 \mathrm{DBC}$ were observed throughout the study, although this appeared to be primarily a result of the delay (e.g., days) between herbicide applications rather than differences in efficacy.

The greatest differences among glyphosate timings were observed 1-8 DAC (Fig. 1A and B). Thereafter, green cover was reduced to $1.8 \%$ or less among all glyphosate treatments, greatly diminishing the biological meaningfulness of statistical differences detected on later observation dates. Glyphosate applied 7 and 5 DBC had less green cover 1 DAC, compared with applications made 1 or 0 DBC, during both years. Applications 3 DBC, provided a comparable reduction in green turf cover as treatments 7 and 5 DBC in 2015, although was intermediate between 7 and 5 DBC and 1 and $0 \mathrm{DBC}$ on this observation date in 2014.

At 6 and 8 DAC in 2014, no differences were detected among glyphosate applications 7 through $1 \mathrm{DBC}$ with percent green cover ranging from $0.0 \%$ to $3.1 \%$; all these timings had less green cover compared with glyphosate applied $0 \mathrm{DBC}(12.5 \%$ and $6.7 \%$ on 6 and 8 DAC, respectively; Fig. 1A). In 2015, a more rapid decline of percent green cover was observed with all glyphosate application timings, falling below $1.1 \%$ green cover by 6 DAC (Fig. 1B). Differences among glyphosate application timings at 6 DAC in 2015 were observed with 7,5 , and 3 DBC having

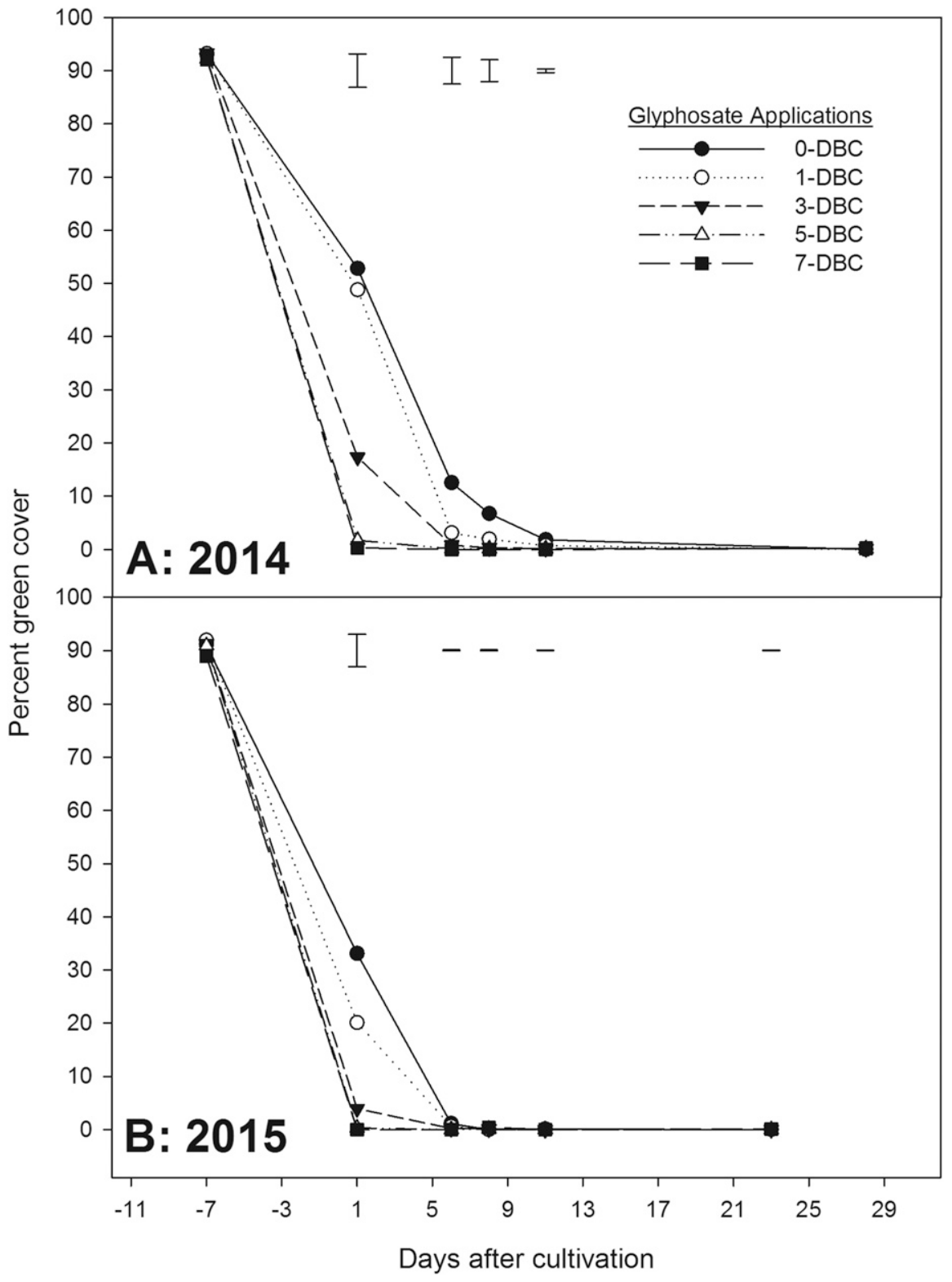

Fig. 1. Glyphosate application timing main effect on percent green cover of creeping bentgrass during 2014 (A) and 2015 (B) in Storrs, CT. Error bars representing Fisher's protected least significant difference test $(\alpha=0.05)$ indicate significant treatment differences within each date. less green cover than $1 \mathrm{DBC}$, and $0 \mathrm{DBC}$ having the greatest green cover. However, these differences were small $(\leq 1.1 \%)$, and appear to have little biological significance on the eventual, long-term efficacy of glyphosate. No increase in green cover was observed in any glyphosate application timing treatments by the last observation date ( 23 or 28 DAC) during either year (Fig. 1A and B).

Cultivation main effect on percent green cover. The cultivation main effect influenced percent green cover 1 DAC during both years of the study (Table 1). Statistical differences were periodically detected among cultivation treatments on various dates thereafter. However, similar to the glyphosate application timing effect, differences between treatments on observation dates after 1 DAC did not appear to be biologically significant because of the low percent cover observed in all treated plots (i.e., $\leq 0.7 \%$ ) on dates where a significant cultivation main effect was detected (Fig. 2A and B). Differences among cultivation treatments 1 DAC were similar during 2014 and 2015. All cultivated plots (i.e., verticutting, core cultivation and verticutting + core cultivation) had $17 \%$ to $36 \%$ less green cover compared with noncultivated plots 1 DAC during both years (Fig. 2A and B). Cultivation treatment effects 1 DAC were due to the physical defoliation and disruption to the turfgrass canopy associated with these mechanical practices. Within cultivation treatments, the combination of verticutting + core-cultivation reduced percent green cover compared with verticutting alone in 2015 or core cultivation alone during either year, 1 DAC. There was no difference between verticutting alone and core-cultivation alone on this date during 2014 and 2015. The theoretical surface area affected by verticutting alone and corecultivation alone treatments in this study was $7.8 \%$ and $7.7 \%$, respectively which corresponds with the similar effect of these treatments relative to each other on green cover observed 1 DAC.

Interaction of glyphosate timing and cultivation type on percent green cover. A cultivation type by glyphosate application timing interaction was detected 1 DAC in both 2014 and 2015 (Table 1). The interaction remained statistically significant throughout the remainder of the study in 2015 , although as noted previously, percent green cover on these subsequent dates (6-23 DAC) was very low $(0 \%$ to $1.6 \%)$ and relative treatment differences were minimal (data not shown). Therefore, data presented here focus on treatment effects observed 1 DAC during 2014 and 2015, when the greatest differences were observed.

Generally, interaction means indicated that percent green cover declined with increasing days between glyphosate application and cultivation, although the extent of loss in green cover was enhanced with increasingly aggressive cultivation practices (Table 2). No differences between cultivated and noncultivated plots were observed when glyphosate was applied 7 to $5 \mathrm{DBC}$ because 


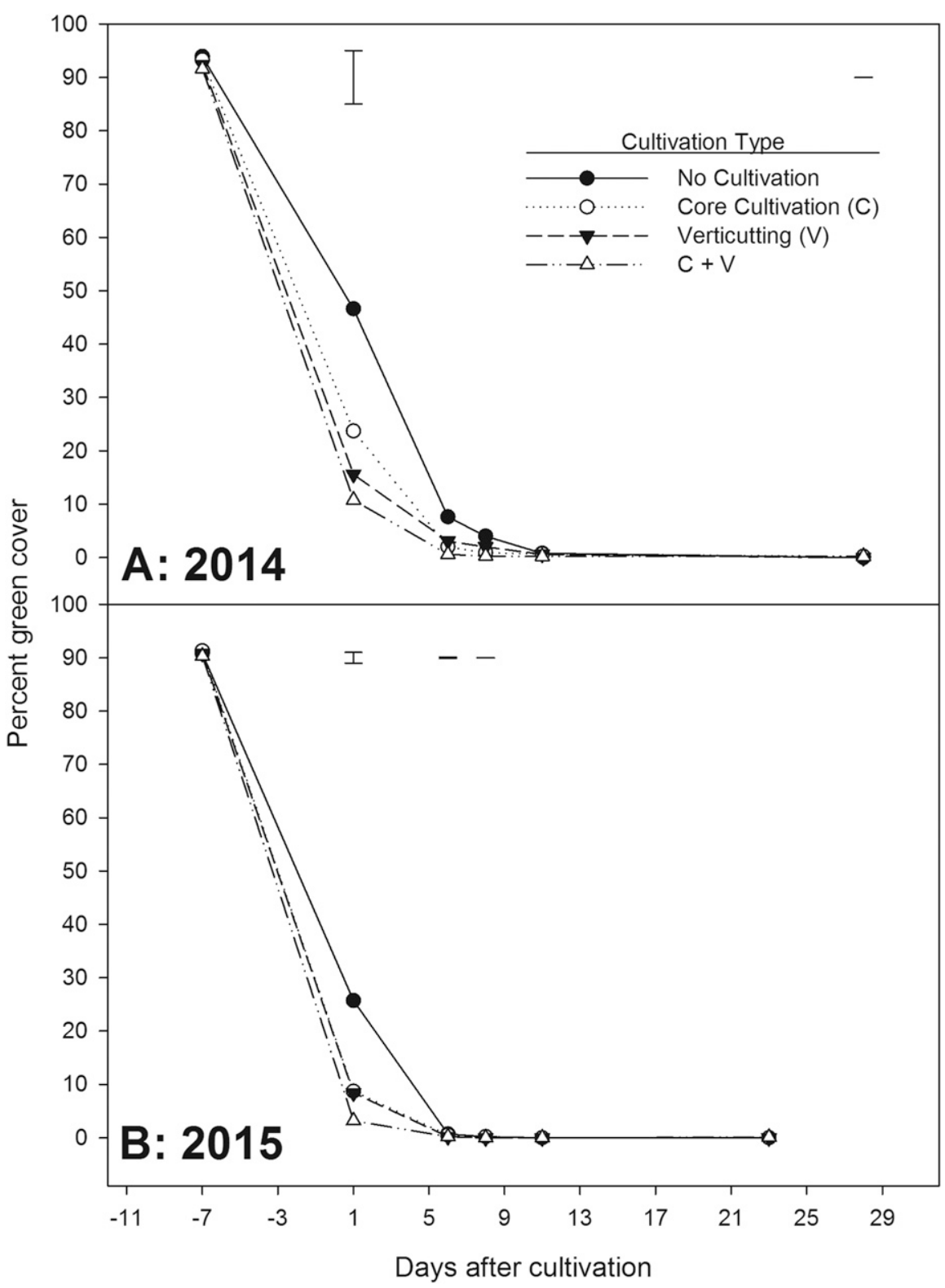

Fig. 2. Cultivation main effect on percent green cover of creeping bentgrass during 2014 (A) and 2015 (B) in Storrs, CT. Error bars representing Fisher's protected least significant difference test $(\alpha=0.05)$ indicate significant treatment differences within each date.

of the limited amount of turf cover present at the time of cultivation in these treatments. All plots treated with glyphosate 7 to 5 DBC contained only $0.0 \%$ to $3.8 \%$ green cover regardless of cultivation at this time during both years. Cultivation differences were more apparent when glyphosate was applied 3 to 0 DBC. All cultivated plots had $37.9 \%$ to $72.3 \%$ or $5.9 \%$ to $62.1 \%$ less green cover compared with noncultivated plots when glyphosate was applied $\leq 3$ DBC in 2014 and 2015, respectively. The combination of verticutting + core-cultivation generally reduced percent green cover compared with core-cultivation alone when glyphosate was applied between 3 and 0 DBC, except no difference was observed when glyphosate was applied 3 DBC during 2015. Whereas, comparisons between the combination cultivation treatment and verticutting-alone differed cultivation), no differences in green cover were observed among glyphosate applications 7 to $3 \mathrm{DBC}$ or 0 to $1 \mathrm{DBC}$. However, earlier applications (i.e., 7 to $3 \mathrm{DBC}$ ) generally had less green cover $(0.7 \%$ to $1.8 \%)$ compared with later applications $(20.7 \%$ to $51.7 \%$ ) 1 DAC during both years (Table 2). An exception was observed in the combination cultivation treatment where there were no differences among all glyphosate application timings 1 DAC in 2015. Conversely, in noncultivated plots, glyphosate application timing had less of an effect on green cover 3 DBC compared with 7 and 5 DBC, although similar to cultivated treatments, the greatest green turf cover was observed in plots treated with glyphosate 1 and 0 DBC in 2014. Glyphosate effect on percent green cover in noncultivated plots was similar to that of the herbicide applied to verticutting and core cultivation plots during 2015.

These data illustrate that percent green cover of cultivated plots was less than or equal to noncultivated plots regardless of glyphosate timing 1 DAC. Moreover, percent green cover for all treatments was $0 \%$ to $0.2 \%$ and $0 \%$ to $0.1 \%$ among all treatments on the final observation date in 2014 and 2015 , respectively (data not shown). Therefore, counter to current label recommendations, cultivation practices performed $\leq 7$ DBC do not reduce the glyphosate efficacy on creeping bentgrass based on data from this study.

Rate of green cover decline. Rate of green cover decline was modeled to characterize the efficacy of glyphosate application timing and cultivation practices independent of calendar date. Generally, the number of days until green cover reached $1 \%\left(\mathrm{GC}_{1}\right)$ ranged from 6.6 to 11.1 in 2014 , and 5.2 to 6.9 in 2015 (Table 3). More rapid decline in 2015 may be due to increased mean air temperatures during the application periods (Fig. 3) (Jordan, 1977; McWhorter et al., 1980). However, analysis of variance results indicate $\mathrm{GC}_{1}$ was influenced by an interaction between glyphosate timing and cultivation type in 2014, and a cultivation main effect in 2015 (Table 3).

In 2014, the interaction indicated that within each cultivation type, $\mathrm{GC}_{1}$ was equivalent among plots receiving glyphosate 7 to 3 DBC (Table 4). Similarly, glyphosate applications applied 1 to $0 \mathrm{DBC}$ were also generally comparable with each other within cultivation type, except verticutting alone plots where glyphosate applied $0 \mathrm{DBC}$ took $5.6 \mathrm{~d}$ longer than $1 \mathrm{DBC}$ to reach $1 \%$ green cover. Interestingly, plots treated with glyphosate soon before cultivation (i.e., 1 to $0 \mathrm{DBC}$ ) had greater $\mathrm{GC}_{1}$ than those treated $3 \mathrm{DBC}$, and were greater than or equal to plots treated with glyphosate 7 to $5 \mathrm{DBC}$, regardless of cultivation type. While these data appear to suggest that cultivation soon after glyphosate application may reduce herbicide efficacy, it is important to note that the slowdown in rate of decline in plots treated with glyphosate 1 and $0, \mathrm{DBC}$ was also observed in plots which received no 
Table 2. Interaction of glyphosate application timing and cultivation type influencing percent green cover $1 \mathrm{~d}$ after cultivation on creeping bentgrass fairway turf in Storrs, CT during 2014 and 2015.

\begin{tabular}{|c|c|c|c|c|}
\hline \multirow{4}{*}{ Glyphosate timing $^{z}$} & \multicolumn{4}{|c|}{ Cultivation type } \\
\hline & Verticutting $^{y}$ & Core cultivation $^{\mathrm{x}}$ & Verticutting + core cultivation & $\overline{\text { No cultivation }}$ \\
\hline & \multicolumn{4}{|c|}{ Percent green cover $(0 \%$ to $100 \%)$} \\
\hline & & & & \\
\hline $7 \mathrm{DBC}^{\mathrm{w}}$ & $0.2 \mathrm{bA}^{\mathrm{v}}$ & $0.4 \mathrm{bA}$ & $0.0 \mathrm{bA}$ & $0.4 \mathrm{cA}$ \\
\hline $5 \mathrm{DBC}$ & $1.0 \mathrm{bA}$ & $1.6 \mathrm{bA}$ & $0.4 \mathrm{bA}$ & $3.8 \mathrm{cA}$ \\
\hline $3 \mathrm{DBC}$ & $6.9 \mathrm{bC}$ & $12.9 \mathrm{bB}$ & $4.9 \mathrm{bC}$ & $44.4 \mathrm{bA}$ \\
\hline $1 \mathrm{DBC}$ & $29.4 \mathrm{aC}$ & $51.1 \mathrm{aB}$ & $25.5 \mathrm{aC}$ & $89.0 \mathrm{aA}$ \\
\hline $0 \mathrm{DBC}$ & $40.7 \mathrm{aB}$ & $52.3 \mathrm{aB}$ & $22.9 \mathrm{aC}$ & $95.2 \mathrm{aA}$ \\
\hline \multicolumn{5}{|l|}{2015} \\
\hline $7 \mathrm{DBC}^{\mathrm{w}}$ & $0.0 \mathrm{bA}^{\mathrm{y}}$ & $0.0 \mathrm{bA}$ & $0.0 \mathrm{aA}$ & $0.0 \mathrm{cA}$ \\
\hline $5 \mathrm{DBC}$ & $0.0 \mathrm{bA}$ & $0.1 \mathrm{bA}$ & $0.2 \mathrm{aA}$ & $1.0 \mathrm{cA}$ \\
\hline $3 \mathrm{DBC}$ & $3.5 \mathrm{bB}$ & $2.1 \mathrm{bB}$ & $0.7 \mathrm{aB}$ & $9.4 \mathrm{cA}$ \\
\hline $1 \mathrm{DBC}$ & $16.8 \mathrm{aB}$ & $15.0 \mathrm{aB}$ & $3.9 \mathrm{aC}$ & $44.8 \mathrm{bA}$ \\
\hline $0 \mathrm{DBC}$ & $21.5 \mathrm{aC}$ & $26.4 \mathrm{aB}$ & $11.3 \mathrm{aD}$ & $73.4 \mathrm{aA}$ \\
\hline
\end{tabular}

${ }^{\mathrm{z}}$ Glyphosate was applied at a rate of $5.7 \mathrm{~kg} \cdot \mathrm{ha}{ }^{-1}$ using a handheld $\mathrm{CO}_{2}$ powered spray boom outfitted with a single AI9504E flat fan nozzle calibrated to deliver $406 \mathrm{~L} \cdot \mathrm{ha}^{-1}$ at $137.9 \mathrm{kPa}$. Glyphosate was applied 7, 5, 3,1 , or $0 \mathrm{~d}$ before cultivation.

${ }^{\mathrm{y}}$ Verticutting treatments were conducted in two directions with $2 \mathrm{~mm}$ blades at $52 \mathrm{~mm}$ spacing at a depth equal to the soil-thatch interface $(\approx 2.5 \mathrm{~cm})$.

${ }^{\mathrm{x}}$ Core-cultivation was performed with $1.6 \mathrm{~cm}$ o.d. hollow-tines on a $5 \times 5 \mathrm{~cm}$ spacing to a depth of $5 \mathrm{~cm}$. ${ }^{\mathrm{w}}$ Days before cultivation.

${ }^{\mathrm{v}}$ Means followed by the same lower case letter within a column are not significantly different based on Fisher's protected least significant difference test $(\alpha=0.05)$. Means followed by the same upper case letter within a row are not significantly different based on Fisher's protected least significant difference test $(\alpha=$ $0.05)$.

Table 3. Analysis of variance (ANOVA) for glyphosate application timing and cultivation type effects on the number of days until percent green cover declined to $1 \%\left(\mathrm{GC}_{1}\right)$ on creeping bentgrass fairway turf in Storrs, CT during 2014 and 2015.

\begin{tabular}{|c|c|c|}
\hline \multirow[b]{3}{*}{ Main effect } & \multicolumn{2}{|c|}{$\mathrm{GC}_{1}$} \\
\hline & 2014 & 2015 \\
\hline & \multicolumn{2}{|c|}{ Days until green cover $=1 \%$} \\
\hline \multicolumn{3}{|l|}{ Glyphosate timing $^{z}$} \\
\hline $7-\mathrm{DBC}^{\mathrm{y}}$ & $6.6 \mathrm{c}^{\mathrm{x}}$ & 6.9 \\
\hline 5 -DBC & $6.7 \mathrm{c}$ & 6.9 \\
\hline 3-DBC & $5.7 \mathrm{c}$ & 5.4 \\
\hline $1-\mathrm{DBC}$ & $8.9 \mathrm{~b}$ & 5.2 \\
\hline 0 -DBC & $11.1 \mathrm{a}$ & 5.8 \\
\hline \multicolumn{3}{|l|}{ Cultivation type } \\
\hline Verticutting $^{\mathrm{w}}$ & 8.5 & $5.7 \mathrm{bc}$ \\
\hline Core cultivation $^{v}$ & 7.4 & $6.2 \mathrm{~b}$ \\
\hline Verticutting + core cultivation & 6.6 & $4.9 \mathrm{c}$ \\
\hline No cultivation & 7.6 & $7.4 \mathrm{a}$ \\
\hline Source of variation & \multicolumn{2}{|c|}{ ANOVA } \\
\hline Glyphosate timing & $* * *$ & NS \\
\hline Cultivation type & NS & ** \\
\hline Glyphosate $\times$ culivation & ** & NS \\
\hline
\end{tabular}

${ }^{\mathrm{z}}$ Glyphosate was applied at a rate of $5.7 \mathrm{~kg} \cdot \mathrm{ha}^{-1}$ using a hand held $\mathrm{CO}_{2}$ powered spray boom outfitted with a single AI9504E flat fan nozzle calibrated to deliver $406 \mathrm{~L} \cdot \mathrm{ha}^{-1}$ at $137.9 \mathrm{kPa}$. Glyphosate was applied 7, 5 , 3,1 , or $0 \mathrm{~d}$ before cultivation (DBC).

${ }^{\mathrm{y}}$ Days before cultivation.

${ }^{\mathrm{x}}$ Treatment means followed by the same letter, within each column, are not significantly different based on Fisher's protected least significant difference test $(\alpha=0.05)$.

${ }^{\mathrm{w}}$ Verticutting treatments were conducted using a Graden SW04 Swing-Wing Verticutter (Graden Industries, Thomastown, Victoria, Australia) with $2 \mathrm{~mm}$ blades at $52 \mathrm{~mm}$ spacing. Plots were verticut in two directions to a depth that reached just below the thatch layer and scratched the soil surface $(\approx 2.5$ $\mathrm{cm})$.

${ }^{\mathrm{v}}$ Core cultivation treatments were conducted using a Toro ProCore 648 (The Toro Company, Bloomington, $\mathrm{MN}$ ) outfitted with $1.6 \mathrm{~cm}$ o.d. hollow-tines to a depth of $5 \mathrm{~cm}$ with $5 \mathrm{~cm}$ spacing. NS $=$ nonsignificant; $* * *, * * *$ Significant at the $0.05,0.01$, and 0.001 probability levels, respectively.

cultivation (Table 4). The reduced rate of green cover decline observed when cultivation occurred 1 to 0 DBC is more likely due to irrigation practices used in the study. Limited irrigation was applied to the study area from the time glyphosate treatments were initiated until cultivation treatments were completed. Thereafter, irrigation was applied daily every $3 \mathrm{~h}$ for the duration of the study to simulate
$0 \mathrm{DBC}$, no difference was observed between the no cultivation treatment and verticutting + core-cultivation or core-cultivation alone when glyphosate was applied on the same day (i.e., 0 DBC). Only verticutting alone treatments differed from the no-cultivation treatment with the former requiring 5.1 additional days until green cover declined to $1 \%$ when glyphosate was applied 0 DBC. Conversely, the cultivation main effect observed during 2015 indicated that all cultivation treatments reduced $\mathrm{GC}_{1} 1.7-2.5 \mathrm{~d}$ compared with the no cultivation treatment, regardless of glyphosate application timing (Table 3). Green cover declined at the greatest rate in verticutting + core-cultivation and verticutting-alone treatments, although core-cultivation treatments did not differ from verticutting-alone.

These data indicate that cultivation 1-7 d after glyphosate application has no detrimental effect on the rate of glyphosate activity, and in some cases may hasten decline of creeping bentgrass fairway turf. These results seemingly contradict those of Burt (1980) who reported glyphosate $(0.56-4.48 \mathrm{~kg}$ a.i./ha) control was reduced when tillage occurred 1 or $3 \mathrm{~d}$ after treatment in $30-\mathrm{cm}$ tall torpedograss. Other studies evaluating glyphosate translocation in grasses have demonstrated that the herbicide moves throughout the plant within the first $4 \mathrm{~d}$ after application (Bingham et al., 1980; Claus and Behren, 1976; Segura et al., 1978). These previous studies suggest that cultivation within $4 \mathrm{~d}$ of glyphosate application could reduce herbicide efficacy by preventing adequate translocation of the herbicide throughout the plant. However, these studies evaluated grasses maintained at greater heights of cut (e.g., $14-30 \mathrm{~cm}$ ). In the current study, glyphosate controlled creeping bentgrass with no regrowth observed through the conclusion of the study (i.e., 23-28 d) regardless of glyphosate application timing or cultivation practices. Glyphosate was applied at $3.42 \mathrm{~kg}$ a.i./ha to creeping bentgrass maintained at $1.3 \mathrm{~cm}$ height of cut. It is possible that under these conditions, more rapid and thorough translocation of glyphosate may occur due to the diminutive size of the plant, relatively high application rate, and uniformity of spray coverage throughout the canopy. Thus, cultivation following glyphosate application to fairway turf does not appear to be as detrimental to herbicide efficacy as it may be to plants maintained at greater heights of cut.

Results from this study indicate that cultivation of fairway turf within $7 \mathrm{~d}$ of glyphosate application is not detrimental to long-term herbicide efficacy, and in some cases may actually enhance the rate of decline of glyphosate treated turf. However, rate of turf decline (i.e., $\mathrm{GC}_{1}$ ) may be reduced when glyphosate is applied within $3 \mathrm{~d}$ of cultivation, if frequent irrigation follows. Furthermore, this study suggests that it may be possible to shorten at least one component of an overall renovation project by reducing the interval between glyphosate application and seedbed preparation (i.e., cultivation practices) from the current recommendation of $7 \mathrm{~d}$, to as little as $0 \mathrm{DBC}$ without 


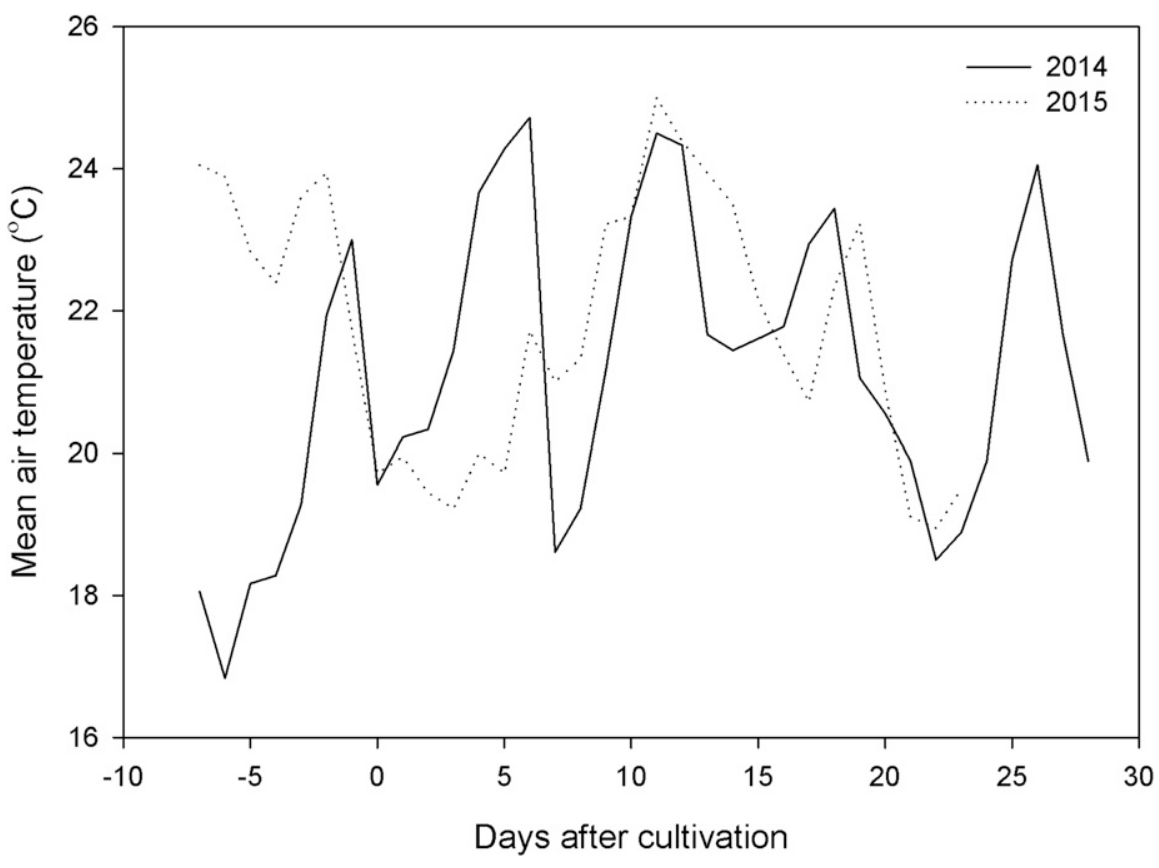

Fig. 3. Mean daily air temperatures from 20 June to 25 July 2014 and 20 July to 29 Aug. 2015 at the Plant Science Research and Education Facility in Storrs, CT.

Table 4. Interaction of glyphosate application timing and cultivation type effects on the number of days until percent green cover declined to $1 \%\left(\mathrm{GC}_{1}\right)$ on creeping bentgrass fairway turf in Storrs, $\mathrm{CT}$ during 2014.

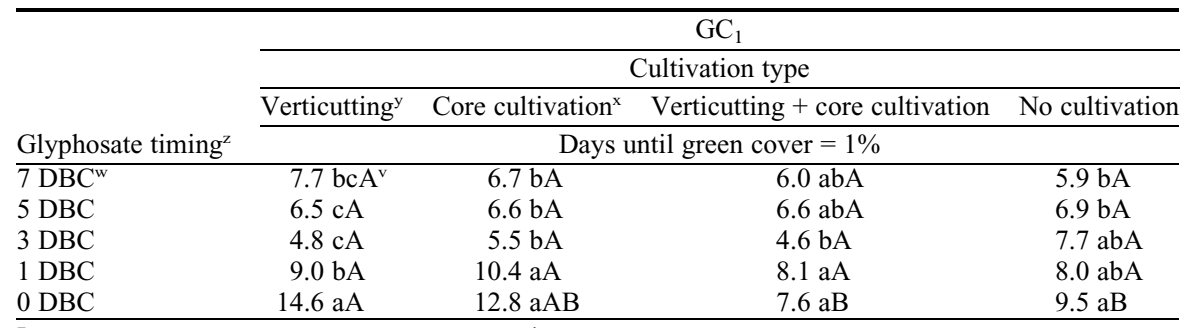

${ }^{\mathrm{z}}$ Glyphosate was applied at a rate of $5.7 \mathrm{~kg} \cdot \mathrm{ha}^{-1}$ using a handheld $\mathrm{CO}_{2}$ powered spray boom outfitted with a single AI9504E flat fan nozzle calibrated to deliver $406 \mathrm{~L} \cdot \mathrm{ha}^{-1}$ at $137.9 \mathrm{kPa}$. Glyphosate was applied 7, 5, 3,1 , or $0 \mathrm{~d}$ before cultivation (DBC).

${ }^{\mathrm{y}}$ Verticutting treatments were conducted using a Graden SW04 Swing-Wing Verticutter (Graden Industries, Thomastown, Victoria, Australia) with $2 \mathrm{~mm}$ blades at $52 \mathrm{~mm}$ spacing. Plots were verticut in two directions to a depth that reached just below the thatch layer and scratched the soil surface $(\approx 2.5$ $\mathrm{cm})$.

${ }^{\mathrm{x}}$ Core Cultivation treatments were conducted using a Toro ProCore 648 (The Toro Company) outfitted with $1.6 \mathrm{~cm}$ o.d. hollow-tines to a depth of $5 \mathrm{~cm}$ with $5 \mathrm{~cm}$ spacing.

${ }^{\mathrm{w}}$ Days before cultivation.

${ }^{\mathrm{v}}$ Means followed by the same lower case letter within the same column are not significantly different based on Fisher's protected least significant difference test $(\alpha=0.05)$. Means followed by the same upper case letter within the same row are not significantly different based on Fisher's protected least significant difference test $(\alpha=0.05)$.

a reduction in efficacy. However, applying glyphosate and cultivating large areas, such as a golf course fairway, on the same day are likely impractical. Therefore, turfgrass practitioners renovating existing creeping bentgrass

\section{Literature Cited}

Amrhein, N., J. Schab, and H.C. Steinrucken. 1980 The mode of action of the herbicide glyphosate. Sci. Nat. 67:356-357.

Anonymous. 2010. Roundup pro concentrate label. Monsanto Company, St. Louis, MO.

Bauer, S., B.P. Horgan, E. Watkins, A. Hathaway, R. Calhoun, and K. Frank. 2012. Establishment of creeping bentgrass fairways using glyphosate and interseeding. Appl. Turfgrass Sci. 9. doi: 10.1094/ATS-2012-0127-01-RS.

Bonos, S.A. and D.R. Huff. 2013. Cool-season grasses: Biology and breeding, p. 591-660. In: Agronomy monograph, turfgrass. Biology, use, and management, Vol. 56. ASA, CSSA, SSSA, Madison, WI.

Bingham, S.W., J. Segura, and C.L. Foy. 1980 Susceptibility of several grasses to glyphosate. Weed Sci. 28:579-585.

Burt, E.O. 1980. Glyphosate for torpedograss and bermudagrass control. Intl. Turfgrass Soc. Res. J. 3:257-262

Claus, J.S. and R. Behren. 1976. Glyphosate translocation and quackgrass rhizome bud kill. Weed Sci. 24:149-152.

Gomez and Gomez. 1984. Statistical procedures for agricultural research. 2nd ed. John Wiley and Sons, Inc. New York, NY.

Hetherington, P.R., G. Marshall, R.C. Kirkwood, and J.M. Warner. 1998. Absorption and efflux of glyphosate by cell suspensions. J. Expt. Bot. 49:527-533

Jordan, T.N. 1977. Effects of temperature and relative humidity on the toxicity of glyphosate to bermudagrass (Cynodon dactylon). Weed Sci. 25:448-451.

Karcher, D.E. and M.D. Richardson. 2005. Batch analysis of digital images to evaluate turfgrass characteristics. Crop Sci. 45:1536-1539.

Kendrick, D.L. and T.K. Danneberger. 2002 Lack of competitive success of an intraseeded creeping bentgrass cultivar into an established putting green. Crop Sci. 42:16151620

McWhorter, C.G., T.N. Jordan, and G.D. Wills. 1980. Translocation of ${ }^{14} \mathrm{C}$-glyphosate in soybeans (Glycine max) and Johnsongrass (Sorghum halepense). Weed Sci. 28:113-118.

Reicher, Z.J. and G.A. Hardebeck. 2002. Overseeding strategies for converting golf course fairways to creeping bentgrass. HortScience 37:508-510.

Segura, J., S.W. Bingham, and C.L. Foy. 1978 Phytotoxicity of glyphosate to Italian ryegrass (Lolium multiflorum) and red clover (Trifolium pratense). Weed Sci. 216:32-36.

Skorulski, J. 2013. Better grasses make for better fairways. USGA Green Sec. Rec. 51(12):1-3.

Steinrucken, H.C. and N. Amrhein. 1980. The herbicide glyphosate is a potent inhibitor of 5-enolpyruvylshikimic acid-3-phosphate synthase. Biochem. Biophys. Res. Commun. 94:1207-1212.

application to eliminate the existing turf stand and minimize the interval between herbicide application and cultivation or seeding.
Turgeon, A.J. 2005. Turfgrass management. 7th ed. Pearson Education, Inc., Upper Saddle River, NJ. 